\title{
GROWTH AND DEVELOPMENT OF OIL PALM CLONE P164 EXPOSED TO LONG- TERM CARBON DIOXIDE ENRICHMENT IN OPEN TOP CHAMBER
}

\author{
AMANINA, N S*; LINATOC, A C**; HANIFF, $\mathrm{M} \mathrm{H}^{*}$ and ROSLAN, $\mathrm{M} \mathrm{N}^{*}$
}

\begin{abstract}
The carbon dioxide $\left(\mathrm{CO}_{2}\right)$ enrichment study on oil palm clone P164 using open top chamber (OTC) technique was conducted to evaluate the effects on oil palm growth, physiology, bunch production and oil quality. The palms were grown in OTC with two $\mathrm{CO}_{2}$ concentrations; 600 ppm ( $\mathrm{CO}_{2}$-enriched) and ambient 400 ppm (control), and also planted in the field under normal conditions (absolute control). After six years of observation, $\mathrm{CO}_{2}$-enriched palms showed a higher biomass percentage of $22.6 \%$ and $23.7 \%$ than the control and absolute control palms, respectively. The increase in biomass was contributed by rachis length and trunk height with a reading of $689.63 \pm 7.70 \mathrm{~cm}$ and $201.25 \pm 10.18 \mathrm{~cm}$, respectively. This positive growth can be attributed to higher photosynthetic rate (A) of $23.51 \pm 0.57 \mu \mathrm{mol} \mathrm{m} \mathrm{m}^{-2} \mathrm{~s}^{-1}$ and affecting the water use efficiency (WUE) of $5.33 \pm 0.10 \mu \mathrm{mol} \mathrm{mol}{ }^{-1} \mathrm{CO}_{2}$. Enhanced A due to high $\mathrm{CO}_{2}$ level markedly increased clonal palm growth and biomass. Valuable information of this study may be beneficial for the oil palm industry to develop suitable mitigation strategies in the future.
\end{abstract}

Keywords: $\mathrm{CO}_{2}$ enrichment, oil palm growth, oil palm physiology, open top chamber.

Received: 28 December 2020; Accepted: 7 April 2021; Published online: 5 July 2021.

\section{INTRODUCTION}

Carbon dioxide $\left(\mathrm{CO}_{2}\right)$ is the main greenhouse gas that has been increasing in the atmosphere due to anthropogenic activities since the industrial revolution. The contributors are burning of fossil fuel (coal, oil and natural gas) for energy in transportation and machinery, open burning as well as deforestation. These activities release more $\mathrm{CO}_{2}$ to the atmosphere and influence the forest as a natural sink, consequently modifying

\footnotetext{
Malaysian Palm Oil Board,

6 Persiaran Institusi, Bandar Baru Bangi,

43000 Kajang, Selangor, Malaysia.

E-mail: nuramanina@mpob.gov.my

** Faculty of Applied Sciences and Technology,

Universiti Tun Hussein Onn Malaysia,

Pagoh Campus, KM 1, Jalan Panchor,

84600 Muar, Johor, Malaysia.
}

the natural carbon cycle process (Pidwirny, 2006). Future climate scenario predicts rising in $\mathrm{CO}_{2}$ level for the next coming decades, contributing to a warmer climate, influencing rainfall patterns, reducing ice and snow cover, raising sea level and increasing sea acidity. Since 1970 to 2004, its annual emission increased by about $80 \%$ and it is projected to continue to increase as much as $500-1000 \mathrm{ppm}$ by year 2100 (Intergovernmental Panel on Climate Change, 2007). Over half of the global carbon uptake is by plants as $\mathrm{CO}_{2}$ serves as substrates for photosynthesis (Bowes, 1991).

Rising $\mathrm{CO}_{2}$ level markedly affects growth, physiology and chemistry of plant (Ziska, 2008). In plant metabolism, $\mathrm{CO}_{2}$ is broken down into smaller carbon molecules chemically. Glucose is used for respiration process, releasing energy to power up metabolic activities. Photosynthesis process which assimilates carbon, hydrogen and oxygen into organic molecules produces about $96 \%$ 
of the total dry mass of a plant (Marschner, 1995). Since the main components of photosynthesis process are $\mathrm{CO}_{2}$, water and light energy, increasing $\mathrm{CO}_{2}$ availability may affect plant growth and photosynthesis. The direct physiological effects of enriched $\mathrm{CO}_{2}$ atmospheres for plant species are becoming increasingly well-documented (Curtis and Wang, 1998). The fertilising effect of elevated $\mathrm{CO}_{2}$ may give impact to crop productivity and agro-ecosystems (Goudriaan and Unsworth, 1990).

Oil palm (Elaeis guineensis Jacq.) is a perennial crop and classified as $\mathrm{a} \mathrm{C}_{3}$ plant (Corley and Tinker, 2003). It is grown expansively in the tropical regions such as Indonesia, Malaysia, Thailand, West Africa and South America. As the perennial crop, it starts yielding fresh fruit bunches (FFB) three years after planting (YAP) to produce oil palm products mainly involved in the food, oleochemical, and biofuel industries. Oil palm has the highest yield amongst oleaginous crops as it can produce three to 10 times more oil than other oil crops planted on a hectare of land (Barcelos et al., 2015). Its production increased worldwide by over 300\% between 1985 and 2008 and had overtaken soyabean as the major source of vegetable oil in 2006 (Denis, 2017). Tenera palm, which is a cross between Dura and Pisifera varieties, has become the highest yielding variety (Bakuomé et al., 2016). Oil palm cultivation in Malaysia started in 1919 during socio-economic development program with only 3000 ha to a whopping 5.8 million hectares by 2017 (Kushairi et al., 2018). This most efficient oil-bearing crop is the most important commodity in Malaysia as the second largest producer and exporter in the world (Choo, 2012).

Oil palm can use high $\mathrm{CO}_{2}$ level better than $\mathrm{C}_{4}$ plants. More than $90 \%$ of terrestrial plants are $\mathrm{C}_{3}$ plants and elevated $\mathrm{CO}_{2}$ greatly affect their photosynthesis and growth (Makino and Mae, 1999). A study has proven that oil palm seedlings can increase photosynthetic rate (A) and water use efficiency (WUE) by one and five-fold under high $\mathrm{CO}_{2}$ condition (Ibrahim et al., 2010). $\mathrm{CO}_{2}$ is a limiting factor of photosynthesis; hence the impact of elevated $\mathrm{CO}_{2}$ would depend on its photosynthetic acclimation. This acclimation is a change in photosynthetic efficiency of leaves (Ghildiyal and Sharma-Natu, 2000). Photosynthesis acclimation to long-term exposure to elevated $\mathrm{CO}_{2}$ reduces carbon reduction cycle key enzymes and increases nutrient use efficiency (Drake et al., 1997).

However, $\mathrm{CO}_{2}$ enrichment studies on tropical plants particularly the technology and techniques are less characterised (Hawa, 2004). Hence, it is important to recognise how increasing $\mathrm{CO}_{2}$ will impact on crop productivity and food supply in tropical regions especially in Asia. Rising atmospheric $\mathrm{CO}_{2}$ concentration could have far-reaching implications on oil palm growth, bunch production and oil quality in the future. Information on the effects of elevated $\mathrm{CO}_{2}$ to oil palm performance and yield is still insufficient and worth exploring.

\section{MATERIALS AND METHODS}

The study was conducted at the Biosphere Project facility, Malaysian Palm Oil Board (MPOB) Research Station in Kluang, Johor, Malaysia (103 $22^{\prime} 17.62^{\prime \prime} \mathrm{E}$ $1^{\circ} 57^{\prime} 23.79^{\prime \prime} \mathrm{N}$ ) with an elevation of $75 \mathrm{~m}$ above sea level. Twelve-month old oil palms (Elaeis guineensis Jacq.) clone P164 were acclimatised for six months before high $\mathrm{CO}_{2}$ application in four units of open top chambers (OTCs). This clone was obtained from the explants of Tenera, high yielding hybrids resulting from crosses between Dura and Pisifera varieties. Clone P164 had $30.6 \%$ oil to bunch ratio $(\mathrm{O} / \mathrm{B})$ and $8.71 \mathrm{t}$ of crude palm oil (CPO) ha $\mathrm{ha}^{-1} \mathrm{yr}^{-1}$ compared to clone P162 batch (Tarmizi, 2009). The OTC was $9 \mathrm{~m}$ in diameter and $10 \mathrm{~m}$ in height, suitable for oil palm growth in a normal field condition with triangular (9 $\mathrm{m} \times 9 \mathrm{~m} \times 9 \mathrm{~m})$ planting method. Each OTC consisted of a cylindrical concrete structure with an aluminium frame for a transparent multiwall polycarbonate sheet, which was $6 \mathrm{~mm}$ thick and had direct solar transmission of $76 \%$ (Sabic Innovative Plastics, USA) and a truncated top at $45^{\circ}$ angle.

All palms were grown in the OTCs at high concentration of $\mathrm{CO}_{2}(600 \mathrm{ppm})$ and ambient $\mathrm{CO}_{2}$ level (control) at $400 \mathrm{ppm}$, and planted in the field under normal conditions (absolute control) with four replicates for each treatment. $\mathrm{CO}_{2}$ gas $(99.8 \%$ purity) was injected at 10 litres per min twice per day at 0900 and 1040 (during active photosynthesis period), with each session lasting for $10 \mathrm{~min}$. The injected $\mathrm{CO}_{2}$ was then mixed with the available air using blower fans located at the base of the OTC. Blower fans were simultaneously used at low speed $\left(<0.5 \mathrm{~ms}^{-1}\right)$ to disperse the $\mathrm{CO}_{2}$ evenly throughout the chamber and to help remove any leaf boundary layer on the leaf surface that would hinder $\mathrm{CO}_{2}$ diffusion into the leaf mesophyll (Aldrich and Bartok, 1994).

Oil palm petiole width and thickness; the number, length and width of leaflets; and the rachis length of frond 17 were measured and recorded every six months to determine palm growth and biomass production. Leaves and trunk dry weight, and leaf area of oil palm were estimated using Hardon et al. (1969) and Corley et al. (1971) formulae. The photosynthetic activity, relative leaf stomatal conductance, instantaneous WUE and transpiration rate (E) measurement of frond 17 leaves were recorded every six months consistent with the palm growth measurements. An infrared gas analyser LI6400 Portable Photosynthesis System (LI-COR, 
USA) was used to measure physiological attributes with optimum cuvette conditions at $1000 \mu \mathrm{mol} \mathrm{m}{ }^{-2}$ $\mathrm{s}^{-1}$ photosynthetically photon flux density (PPFD), 600 ppm $\mathrm{CO}_{2}$ for $\mathrm{CO}_{2}$-enriched palms and 400 ppm $\mathrm{CO}_{2}$ for control and absolute control palms, $60 \%$ relative humidity and $30^{\circ} \mathrm{C}$ temperature (Ibrahim et al., 2010). This measurement was conducted between 0800 to $1100 \mathrm{hr}$ when photosynthetic activity was active.

Relative leaf chlorophyll reading estimation was measured with a portable Soil Plant Analysis Development (SPAD)-502 (Konica-Minolta Sensing, Japan). The SPAD meter determined the relative amount of chlorophyll present in leaves. Stomatal density was examined from leaf epidermis impressions and observed under a light microscope (Leica DM750, Leica Microsystem, Germany) at 400X magnification. The number of stomata per mm square was recorded.

A flower census was conducted to determine the sex ratio for stress status and foreseen bunch production in the oil palm $\mathrm{CO}_{2}$ enrichment study. The data was recorded every two months based on the oil palm phylotaxy. Assisted pollination was conducted at 3 YAP to introduce outside weevils to the anthesising female inflorescences (ready to be fertilised) in the OTC. Anthesising male inflorescences with fresh pollens were obtained from palms in normal field plot and directly placed next to the anthesising female.

The harvested fruit bunches (two cycles per month) were analysed based on the number of bunch production per palm and total bunch weight per palm. Several bunch quality components such as bunch weight, fruit to bunch weight ratio (F/B) and $\mathrm{O} / \mathrm{B}$ were analysed using Nigerian Institute for Oil Palm Research (NIFOR) bunch analysis method (Blaak et al., 1963). P164 oil palms were fertilised using compound MPOB F4 fertiliser (All Cosmos Industries Sdn. Bhd.) at $9 \mathrm{~kg}$ palm $^{-1} \mathrm{yr}^{-1}$ with three applications per year. The F4 fertiliser is a biochemical fertiliser consisting of plant-based organic matters and effective microorganisms with nutrient analysis of $\mathrm{N}: \mathrm{P}_{2} \mathrm{O}_{5}: \mathrm{K}_{2} \mathrm{O}: \mathrm{MgO}: \mathrm{B}_{2} \mathrm{O}_{3}$ at 9:6:18:2:0.5 (Tarmizi, 2009). Water was applied using six units of micro sprinkler installed at $1 \mathrm{~m}$ distance from the oil palm base (within the fertilisation zone). Water was sprayed from the sprinkler head

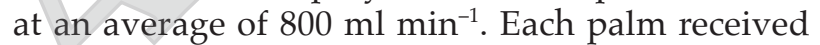
about 48 litres of water daily, with four applications at 0800, 1000, 1400 and $1600 \mathrm{hr}$ and each session lasted for $15 \mathrm{~min}$. Analysis of variance (ANOVA) and multiple comparison were conducted using IBM SPSS Statistics 23 (2014). The test was run using Tukey Honest Significant Difference (HSD) with the least significant difference of 0.05. Averaged data was pooled and shown on yearly basis and error bar represents standard error of mean in that particular data sets.

\section{RESULTS AND DISCUSSION}

After a long exposure to high $\mathrm{CO}_{2}$ condition, P164 palm clones showed $22.7 \%$ and $23.7 \%$ significantly higher standing biomass than the controls and absolute controls, respectively. The aboveground standing woody biomass of black poplar (Populus nigra) significantly increased up to $27 \%$ under elevated $\mathrm{CO}_{2}$ (Liberloo et al., 2006). The total biomass accumulation of Sitka spruce (Picea sitchensis) seedlings increased by $37 \%$ in high $\mathrm{CO}_{2}$ condition and high nitrogen treatment (Murray et al., 2000).

The $\mathrm{CO}_{2}$-enriched palms showed the longest rachis with $689.63 \mathrm{~cm}$ and the highest trunk with $201.50 \mathrm{~cm}$. These values may contribute to a higher biomass. Li et al. (2007) reported that tomato (Solanum lycopersicum) plant biomass, stem height and thickness were $67 \%, 22 \%$ and $24 \%$ higher, respectively when cultivated at high $\mathrm{CO}_{2}$ level. The stem diameter of Scots pine (Pinus sylvestris) enhanced significantly by $60 \%$ in elevated $\mathrm{CO}_{2}$ treatments (Jach and Ceulemans, 1999). However, there was a reduction in the number of leaflets and total leaf area per palm that resulted in low leaf area index (LAI). A decrease in specific leaf area (SLA) of several species of herbs, shrubs and trees from $184 \%$ to $100 \%$ were due to $\mathrm{CO}_{2}$ enrichment and also an artefact from the prolonged exposure (Peńuelas and Matamala, 1990). Ainsworth and Long (2005) reported that the SLA decreased by $6 \%$ depending on the plant functional group and species when exposed to high $\mathrm{CO}_{2}$ concentrations.

Under elevated $\mathrm{CO}_{2}$ levels (800 and $1200 \mu \mathrm{mol}$ $\mathrm{mol}^{-1}$ ), the highest oil palm seedling biomass increment was shown from week 12-15 when the total plant biomass had increased by 1.6-fold from week 12 (Ibrahim et al., 2010). The oil palm seedlings have developed sufficient sink strength to accommodate the elevated $\mathrm{CO}_{2}$ concentrations, thus, increasing the total biomass accumulation (Jeffrey and Richard 1999). The vegetative measurements of $\mathrm{CO}_{2}$-enriched, control and absolute control palms at 6 YAP are shown in Table 1. The standing biomass, rachis length and trunk height annual patterns of all treatments are illustrated in Figures $1 a-c$, respectively.

At $6 \mathrm{YAP}$, the $\mathrm{A}$ of $\mathrm{CO}_{2}$-enriched palm recorded the highest value with $23.51 \mu \mathrm{mol} \mathrm{CO}_{2} \mathrm{~m}^{-2} \mathrm{~s}^{-1}$ compared to control and absolute control palms (Figure 2). Idso and Kimball (1992) investigated that the net photosynthesis of sour orange tree (Citrus aurantium) increased linearly with $\mathrm{CO}_{2}$ by more than $200 \%$. The photosynthesis of several $C_{3}$ grasses, legumes, forbs and woody perennials increased when exposed to elevated $\mathrm{CO}_{2}$ (Kimball et al., 2002). Under elevated $\mathrm{CO}_{2}$ concentration, photosynthesis is enhanced mainly due to an increase in ribulose1,5-bisphosphate (RuBP) carboxylase/oxygenase (Rubisco) activity. Carboxylation of RuBP is catalysed by Rubisco, which is required for the 
TABLE 1. VEGETATIVE MEASUREMENT OF $\mathrm{CO}_{2}$-ENRICHED, CONTROL AND ABSOLUTE CONTROL PALMS AT 6 YAP

\begin{tabular}{lcccccc}
\hline Treatment & RL $(\mathbf{c m})$ & TH $(\mathbf{c m})$ & TD $(\mathbf{c m})$ & F17 TLA & LAI & SB $(\mathbf{k g})$ \\
\hline $\mathrm{CO}_{2}$-enriched & $689.63 \mathrm{a}$ & $201.25 \mathrm{a}$ & $64.50 \mathrm{a}$ & $7.40 \mathrm{a}$ & $3.62 \mathrm{~b}$ & $195.41 \mathrm{a}$ \\
Control & $581.81 \mathrm{~b}$ & $130.38 \mathrm{~b}$ & $65.75 \mathrm{a}$ & $8.15 \mathrm{a}$ & $3.83 \mathrm{~b}$ & $159.26 \mathrm{~b}$ \\
Absolute control & $549.27 \mathrm{c}$ & $101.19 \mathrm{c}$ & $64.00 \mathrm{a}$ & $7.75 \mathrm{a}$ & $4.43 \mathrm{a}$ & $158.06 \mathrm{c}$ \\
\hline
\end{tabular}

Note: RL - rachis length; TH - trunk height; TD - trunk diameter; F17 TLA - frond 17 true leaf area; LAI - leaf area index; SB - standing biomass. Distinct letters in the row indicate significant differences according to Tukey's HSD test at $p \leq 0.05$.

(a)

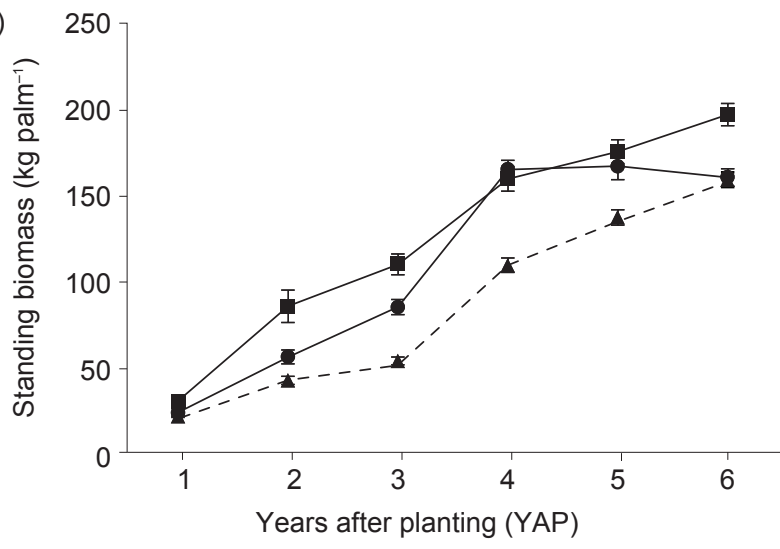

(b)

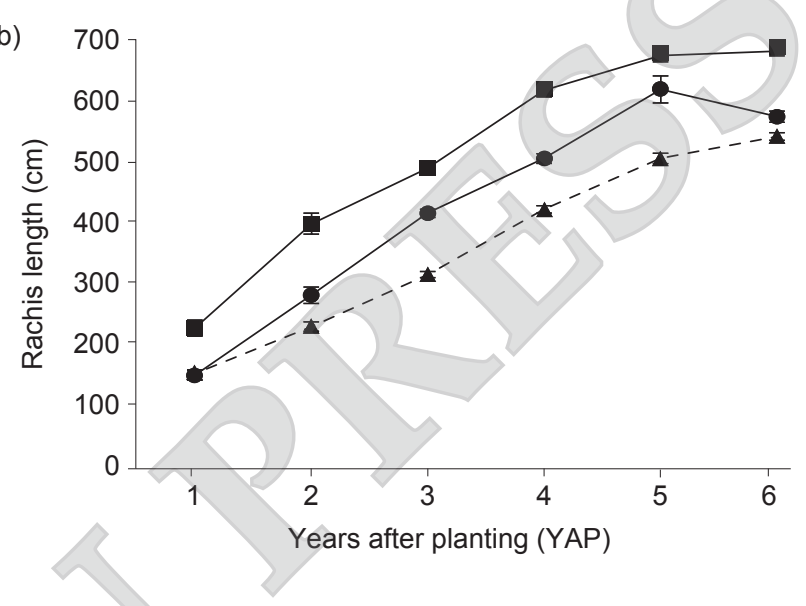

(c)

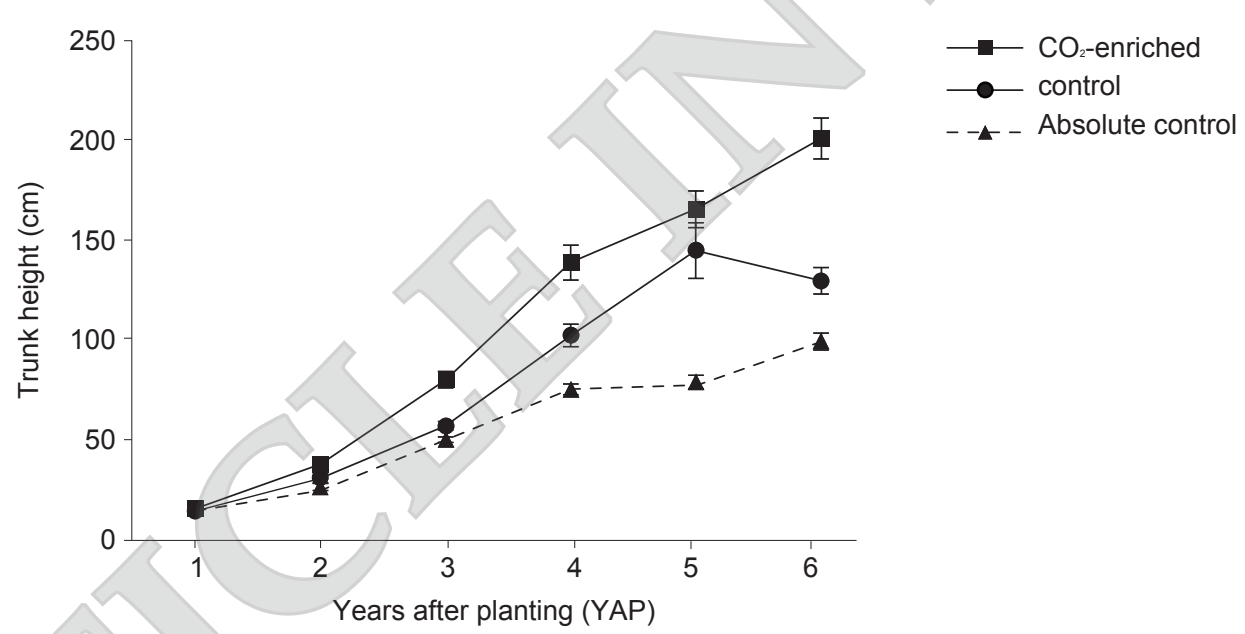

Note: Annual data presented is an averaged value of 6-month intervals data. Error bar represents standard error of mean.

Figure 1. Standing biomass (a) rachis length, (b) trunk height, (c) of $\mathrm{CO}_{2}$-enriched, control and absolute control palms during 6 YAP.

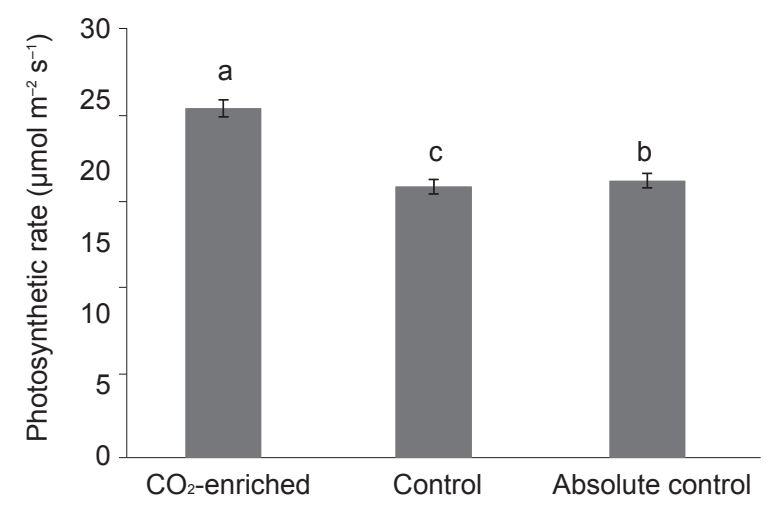

Note: Mean values with different letters differ significantly by Tukey's HSD test at $p \leq 0.05$. Error bar represents standard error of mean.

Figure 2. Photosynthetic rate (A) of $\mathrm{CO}_{2}$-enriched, control and absolute control palms at 6 YAP. 
TABLE 2. LEAF STOMATA DENSITY AT FROND 17 OF $\mathrm{CO}_{2}$-ENRICHED, CONTROL AND ABSOLUTE CONTROL PALMS AT 6 YAP

\begin{tabular}{lc}
\hline Treatment & F17 (pores $\left./ \mathbf{m m}^{2}\right)$ \\
\hline $\mathrm{CO}_{2}$-enriched & $102.50 \pm 3.78 \mathrm{a}$ \\
Control & $106.67 \pm 3.83 \mathrm{a}$ \\
Absolute control & $103.42 \pm 3.04 \mathrm{a}$ \\
\hline
\end{tabular}

Note: Distinct letters in the row indicate significant differences according to ANOVA at $p \leq 0.05$.

fixation of $\mathrm{CO}_{2}$ but also utilises $\mathrm{O}_{2}$ as a substrate to oxygenate RuBP in photorespiration process (Makino and Mae, 1999). Plant exposed to long-term $\mathrm{CO}_{2}$ experiences a photosynthetic down-regulation in both Free-Air Carbon Dioxide Enrichment (FACE) studies (Ainsworth and Long, 2005) and chamber experiments (Warren et al., 2014). This condition is known as photosynthetic acclimation. Ainsworth et al. (2003) found that white clover grown under elevated $\mathrm{CO}_{2}(600 \mathrm{ppm})$ for eight years retained a $37 \%$ increase in photosynthesis after acclimation was observed. These findings suggest that the final growth response to the rising $\mathrm{CO}_{2}$ is generally determined by plant acclimatisation magnitude (Thompson et al., 2017).

Enhanced A value influences an increase in instantaneous WUE value of $5.33 \mu \mathrm{mol} \mathrm{mol}{ }^{-1} \mathrm{CO}_{2}$ (Figure 3). WUE of wheat (Triticum aestivum) was enhanced in enriched $\mathrm{CO}_{2}$ concentrations, leading to higher WUE with more $\mathrm{N}$ supply (Li et al., 2003). Increased WUE occurred by partial closure of stomata when exposed to high $\mathrm{CO}_{2}$ levels (Eamus, 1991). Plants exposed to high $\mathrm{CO}_{2}$ have also been found to maintain higher total water potentials; and to have greater root-to-shoot ratios, increased biomass and higher resistance to drought than those grown at ambient $\mathrm{CO}_{2}$. Elevated $\mathrm{CO}_{2}$ alters plant structure (tracheid anatomy or leaf specific conductivity) and may be related to susceptibility to xylem cavitation or environmental conditions in which embolism is expected to occur (Tyree and Alexander, 1993).

Upon enrichment of $\mathrm{CO}_{2}$, oil palm showed a decreased stomatal conductance $\left(\mathrm{g}_{\mathrm{s}}\right)$ and $\mathrm{E}$ (Figures 4 and 5). Forest species showed a significant

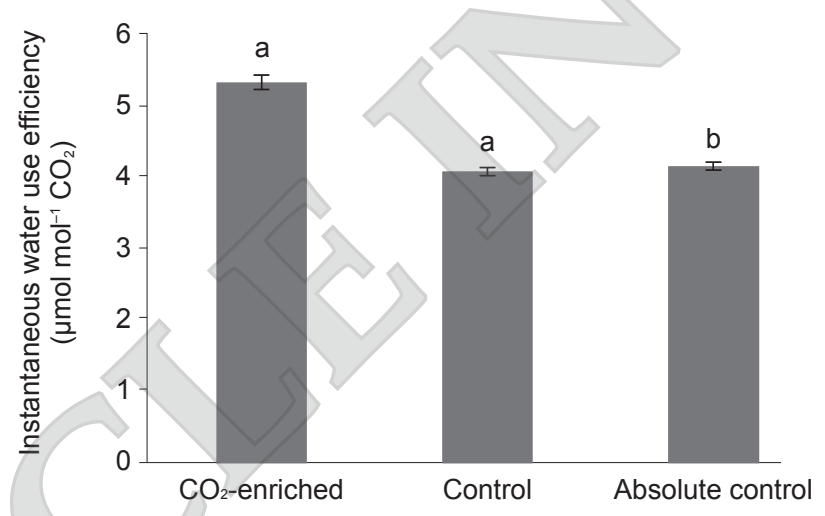

Note: Mean values with different letters differ significantly by Tukey's HSD test at $p \leq 0.05$. Error bar represents standard error of mean.

Figure 3. Instantaneous water use efficiency of $\mathrm{CO}_{2}$-enriched, control and absolute control palms at 6 YAP.

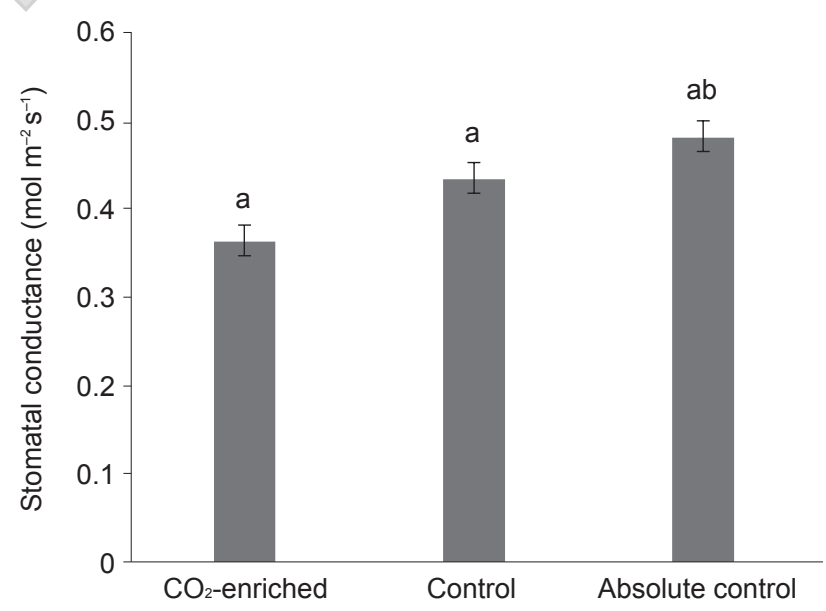

Note: Mean values with different letters differ significantly by Tukey's HSD test at $p \leq 0.05$. Error bar represents standard error of mean. 


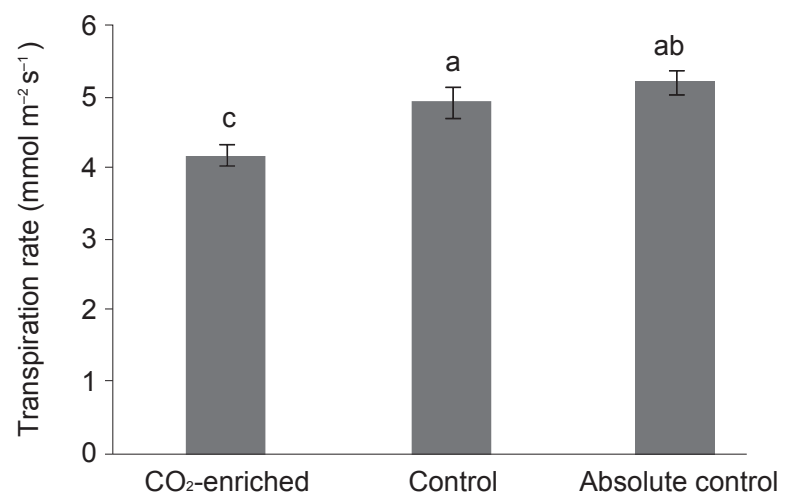

Note: Mean values with different letters differ significantly by Tukey's HSD test at $p \leq 0.05$. Error bar represents standard error of mean.

Figure 5. Transpiration rate of $\mathrm{CO}_{2}$-enriched, control and absolute control palms at 6 YAP.

decrease of $\mathrm{g}_{\mathrm{s}}(21 \%)$ when exposed to elevated $\mathrm{CO}_{2}$ concentration across all studies (Medlyn et al., 2001). The $\mathrm{g}_{\mathrm{s}}$ of $\mathrm{C}_{3}$ grass (Poaceae) decreased on average by $20 \%$ in elevated $\mathrm{CO}_{2}$ concentration using a FACE system (Ainsworth and Long, 2005). Reduced $g_{s}$ under high $\mathrm{CO}_{2}$ conditions influenced WUE for plant growth although $\mathrm{CO}_{2}$ fixation may be limited (Xu et al., 2016). Most forest plants when exposed to increasing $\mathrm{CO}_{2}$ levels possibly reduced $\mathrm{g}_{\mathrm{s}}$ (due to stomatal closure), which will decrease $\mathrm{E}$ by $37 \%-44 \%$ (Kirschbaum and McMilan, 2018).

Absolute control palms showed the highest SPAD readings during 6 YAP (Figure 6), indicating that the absolute control palms grown in ambient $\mathrm{CO}_{2}$ had higher relative leaf chlorophyll content compared to the $\mathrm{CO}_{2}$-enriched palms. According to Idso et al. (1996), sour orange tree (Citrus aurantium) showed higher leaf chlorophyll content in ambient $\mathrm{CO}_{2}$ concentration than $\mathrm{CO}_{2}$-enriched trees throughout the four years of measurement. Chlorophyll content reduction was also observed in other plants subjected to $\mathrm{CO}_{2}$ enrichment. Leaf chlorophyll content of Bintje potato (Solanum tuberosum) was reduced by $5 \%$ when grown in OTC with double ambient $\mathrm{CO}_{2}$ concentration (Bindi et al., 2002). This occurrence may be due to the disruption of chloroplast by starch accumulation (Wulff and Strain, 1981) or chlorophyll loss by the decreasing uptake of $\mathrm{N}$ as the $\mathrm{E}$ decreases due to the $\mathrm{g}_{\mathrm{s}}$ reduction under elevated $\mathrm{CO}_{2}$ (Conroy and Hocking, 1993).

Leaf abaxial stomatal density of clone P164 leaf at frond 17 showed no significant differences between all treatments (Table 2 and Figure 7). High $\mathrm{CO}_{2}$ concentration did not affect stomatal density of poplar trees clones (Poplar trichocarpa) and there was no change in the ratio of adaxial and abaxial stomata between treatments (Radoglou and Jarvis, 1990). Stomatal density of ruderal species, shrub and trees was not affected by long-term exposure to elevated $\mathrm{CO}_{2}$ level. Stomata number and distribution were not affected at the plant community level even after generations of rising $\mathrm{CO}_{2}$ exposure (Bettarini et al., 1998). This result was contrary to the hypothesis made by Paoletti and Gellini (1993): long-term $\mathrm{CO}_{2}$

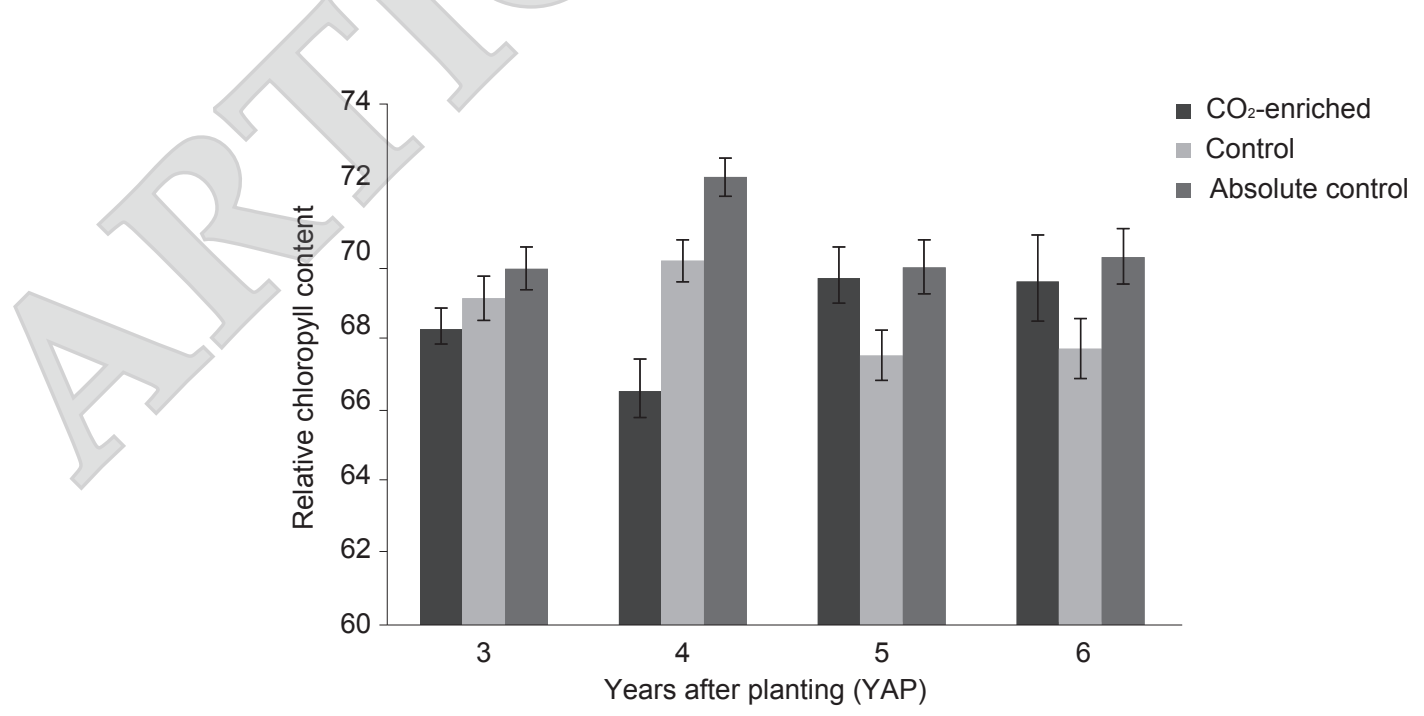

Note: Annual data presented is an averaged value of 6-month intervals data. Error bar represents standard error of mean.

Figure 6. Relative leaf chlorophyll content of $\mathrm{CO}_{2}$-enriched, control and absolute control palms during 6 YAP. 

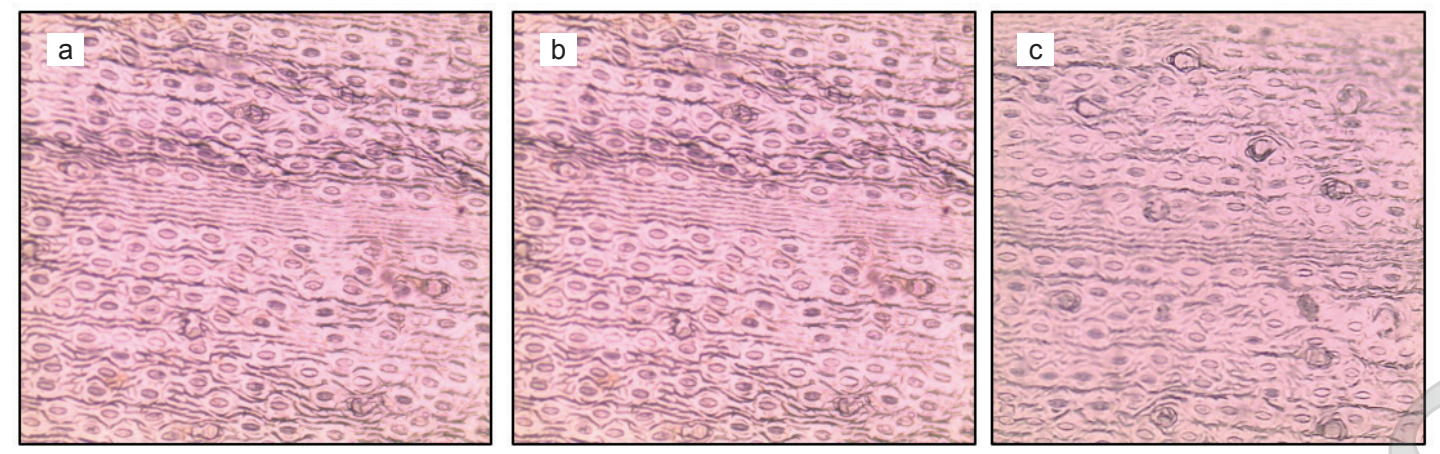

Figure 7. Oil palm clone P164 abaxial leaf stomata (a) $\mathrm{CO}_{2}$-enriched, (b) control, and (c) absolute control at 6 YAP. The photos were taken at $400 \mathrm{X}$ magnification.

exposure may cause stomatal number adaptive modifications.

Sex ratio of $\mathrm{CO}_{2}$-enriched, control and absolute control palms from 2 to 6 YAP were not significantly different as shown in Table 3. The $\mathrm{CO}_{2}$-enriched palm depicted the highest bunch number at 3 YAP with 19 bunches, followed by the control that gave the greatest bunch number at 4 YAP (22 bunches) and the absolute control showed the highest bunch number at 5 and 6 YAP with 17 bunches (Figure 8). The control palm had the highest total bunch weight for three consecutive years (3, 4 and 5 YAP) with $81.85 \mathrm{~kg}, 196.13 \mathrm{~kg}$ and $208.68 \mathrm{~kg}$, respectively. At 6 YAP, the absolute control palm had the highest total bunch weight of $209.18 \mathrm{~kg}$ (Figure 9). However, there were no significant differences of bunch number and total bunch weight between all treatments.

Control palms showed the highest bunch weight and $\mathrm{O} / \mathrm{B}$ meanwhile absolute control palms showed the highest F/B over five-year period (Figures 10a-c). The $\mathrm{CO}_{2}$-enriched palms grown in OTC had the lowest bunch weight due to inefficient pollination. Assisted pollination was conducted to introduce outside weevils to the anthesising female inflorescences in the OTC. The OTC structure prohibited the emergence of Elaeidobius kamerunicus weevils to pollinate the female inflorescences naturally. After the introduction of E. kamerunicus in the oil palm industry, fruit set had increased significantly but fluctuated between seasons (Dhileepan, 1994). According to Haniff and Roslan (2002), poor fruit set and bunch failure were caused by inefficient pollination. Figure 11 illustrates the comparison of fruit formation and fruit size of clone P164 $\left(\mathrm{CO}_{2}\right.$-enriched and control) and DxP palm bunches.

\section{CONCLUSION}

After long exposure to high $\mathrm{CO}_{2}$ concentration, P164 palm clones showed significantly longer rachis and higher trunk, contributing to a significant enhancement of standing biomass. The number of leaflets was reduced, resulting in lower LAI. There was no significant difference in trunk diameter and frond 17 true leaf area (TLA) between $\mathrm{CO}_{2}$-enriched, ambient $\mathrm{CO}_{2}$ (control) and normal field (absolute control) palms.

The $\mathrm{A}$ of $\mathrm{CO}_{2}$-enriched palm increased significantly at 6 YAP. Enhanced A value influenced a greater value of instantaneous WUE and reduced $g_{s}$ and E. Absolute control palms had the highest SPAD

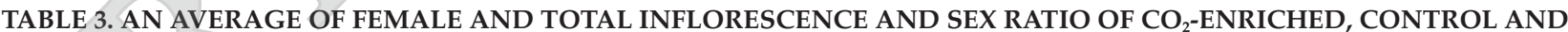 ABSOLUTE CONTROL PALMS POOLED FROM 2 TO 6 YAP}

\begin{tabular}{|c|c|c|c|c|c|c|c|c|c|}
\hline \multirow{3}{*}{ YAP } & \multicolumn{3}{|c|}{ No. of female inflorescence } & \multicolumn{3}{|c|}{ No. of male inflorescence } & \multicolumn{3}{|c|}{ Sex ratio* $(\%)$} \\
\hline & \multicolumn{3}{|c|}{ Treatment } & \multicolumn{3}{|c|}{ Treatment } & \multicolumn{3}{|c|}{ Treatment } \\
\hline & $\begin{array}{c}\mathrm{CO}_{2-}^{-} \\
\text {enriched }\end{array}$ & Control & $\begin{array}{c}\text { Abs. } \\
\text { Control }\end{array}$ & $\begin{array}{c}\mathrm{CO}_{2-}^{-} \\
\text {enriched }\end{array}$ & Control & $\begin{array}{c}\text { Abs. } \\
\text { Control }\end{array}$ & $\begin{array}{c}\mathrm{CO}_{2-}^{-} \\
\text {enriched }\end{array}$ & Control & $\begin{array}{c}\text { Abs. } \\
\text { Control }\end{array}$ \\
\hline 2 & 69 & 69 & 50 & 19 & 11 & 10 & $79.6 a$ & $86.2 \mathrm{a}$ & $84.3 a$ \\
\hline 3 & 239 & 204 & 163 & 44 & 42 & 39 & $82.8 \mathrm{a}$ & $84.2 \mathrm{a}$ & $78.1 \mathrm{a}$ \\
\hline 4 & 371 & 332 & 282 & 56 & 102 & 80 & $87.0 \mathrm{a}$ & $76.5 a$ & $77.9 \mathrm{a}$ \\
\hline 5 & 472 & 450 & 396 & 94 & 115 & 108 & $83.5 \mathrm{a}$ & $79.6 a$ & $78.4 \mathrm{a}$ \\
\hline 6 & 573 & 536 & 496 & 135 & 228 & 147 & $80.9 a$ & $71.2 \mathrm{a}$ & $77.1 \mathrm{a}$ \\
\hline
\end{tabular}

Note: Distinct letters in the row indicate significant differences according to ANOVA at $\mathrm{p} \leq 0.05$.

*Sex ratio is defined as the ratio of female inflorescence to total inflorescences of palms in a year. 


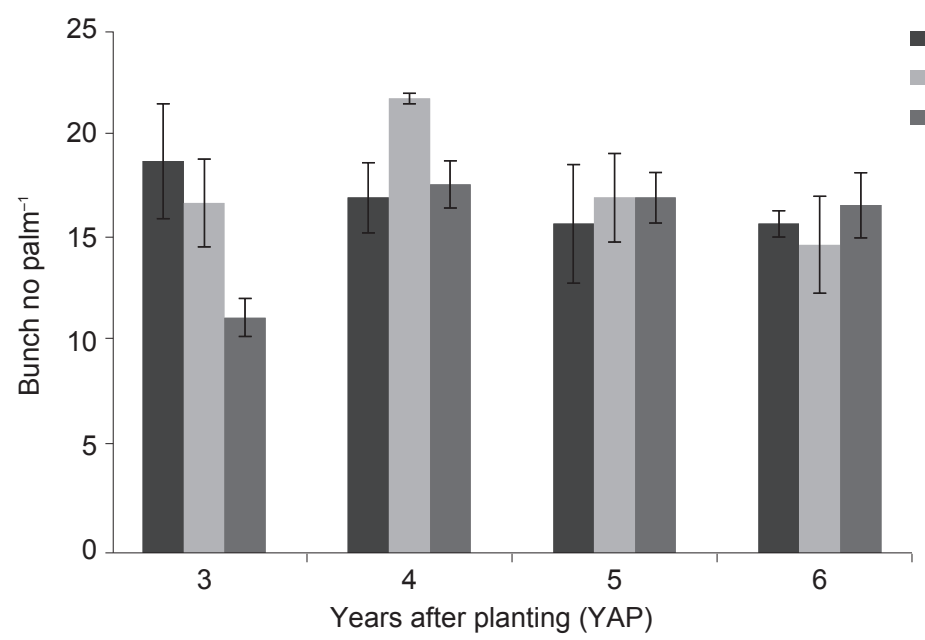

- $\mathrm{CO}_{2}$-enriched

- Control

- Absolute control

Note: Error bar represents standard error of mean.

Figure 8. Bunch number produced by $\mathrm{CO}_{2}$-enriched, control and absolute control palms pooled since three to 6 YAP.

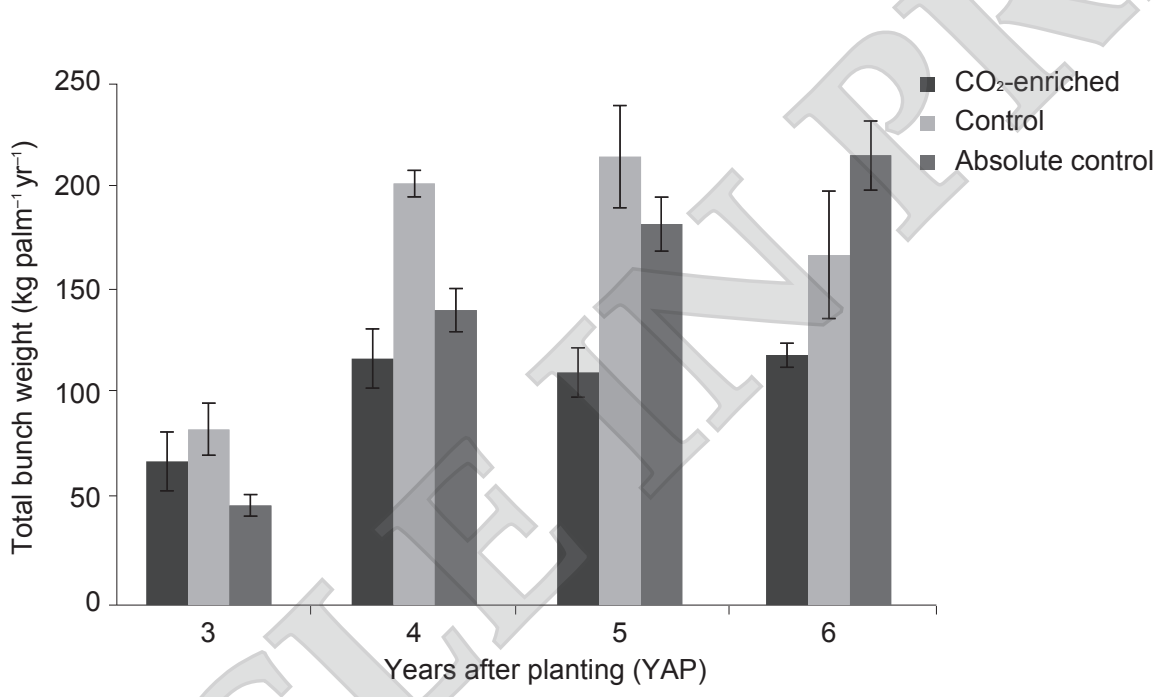

Note: Error bar represents standard error of mean.

Figure 9. Total bunch weight of $\mathrm{CO}_{2}$-enriched, control and absolute control palms collected since three to 6 YAP.

reading, showing that absolute control palms grown in ambient $\mathrm{CO}_{2}$ had higher relative leaf chlorophyll content than the $\mathrm{CO}_{2}$-enriched palms. Reduced chlorophyll content in elevated $\mathrm{CO}_{2}$ condition may be caused by a disruption of chloroplast by starch accumulation. However, leaf stomatal density of frond 17 did not differ between all treatments.

Female inflorescence of $\mathrm{CO}_{2}$-enriched palms was the highest during dry period at 3 YAP. As a result, the $\mathrm{CO}_{2}$-enriched palm produced the highest number of FFB in that particular year. The control palm had the highest total bunch weight for three consecutive years (3, 4 and 5 YAP). Nonetheless, there were no significant differences in bunch number and total bunch weight between all treatments. The $\mathrm{CO}_{2}$-enriched palms grown in OTC showed the lowest bunch weight due to inefficient pollination. Oil palm weevils (Elaeidobius kamerunicus) were unable to enter the OTC and naturally pollinate the anthesising female inflorescences. Therefore, assisted pollination was conducted by taking anthesising male inflorescences to the OTCs to allow the pollination by weevils.

The OTC technology has a potential to study the effects of elevated $\mathrm{CO}_{2}$ and other atmospheric gases on individual plant, but it is not appropriate for large vegetation study. However, there were some limitations, such as the absence of oil palm weevils and artefacts occurrence particularly reduced light quantity. It is suggested that $\mathrm{CO}_{2}$ enrichment study on oil palm could be conducted by using FACE technique. This technique is a better way of estimating how palm growth will change in the future. The information on the actual responses of oil palm to rising atmospheric $\mathrm{CO}_{2}$ is important for the industry to develop suitable mitigation strategies. 
(a)

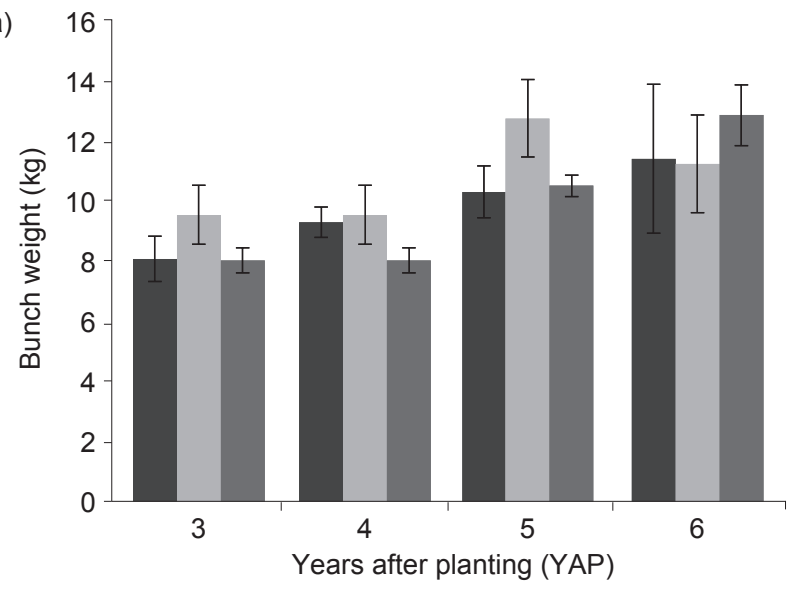

(b)

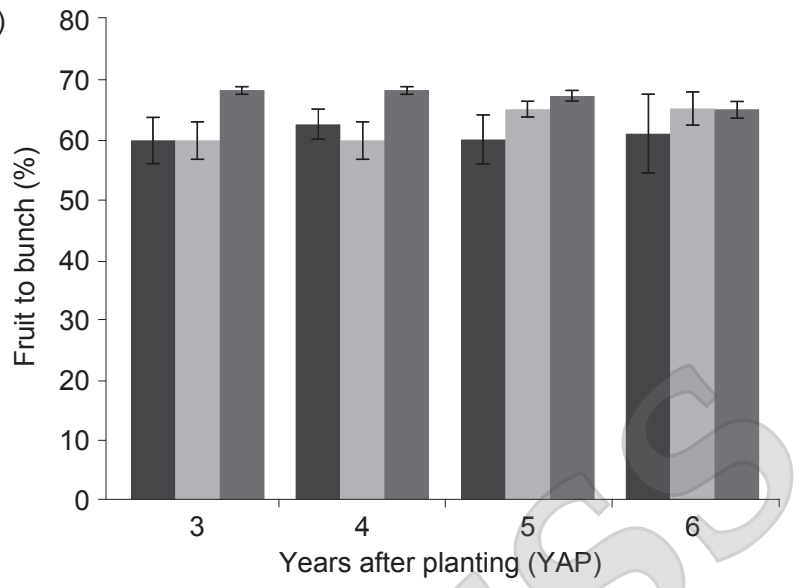

(c)

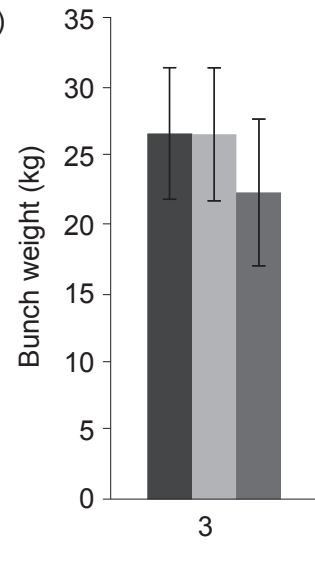

Note: Error bar represents standard error of mean.

Figure 10. (a) Bunch weight, (b) fruit to bunch ratio, and (c) oil to bunch ratio of harvested bunches from $\mathrm{CO}_{2}$-enriched, control and absolute control palms from 3 to 6 YAP.

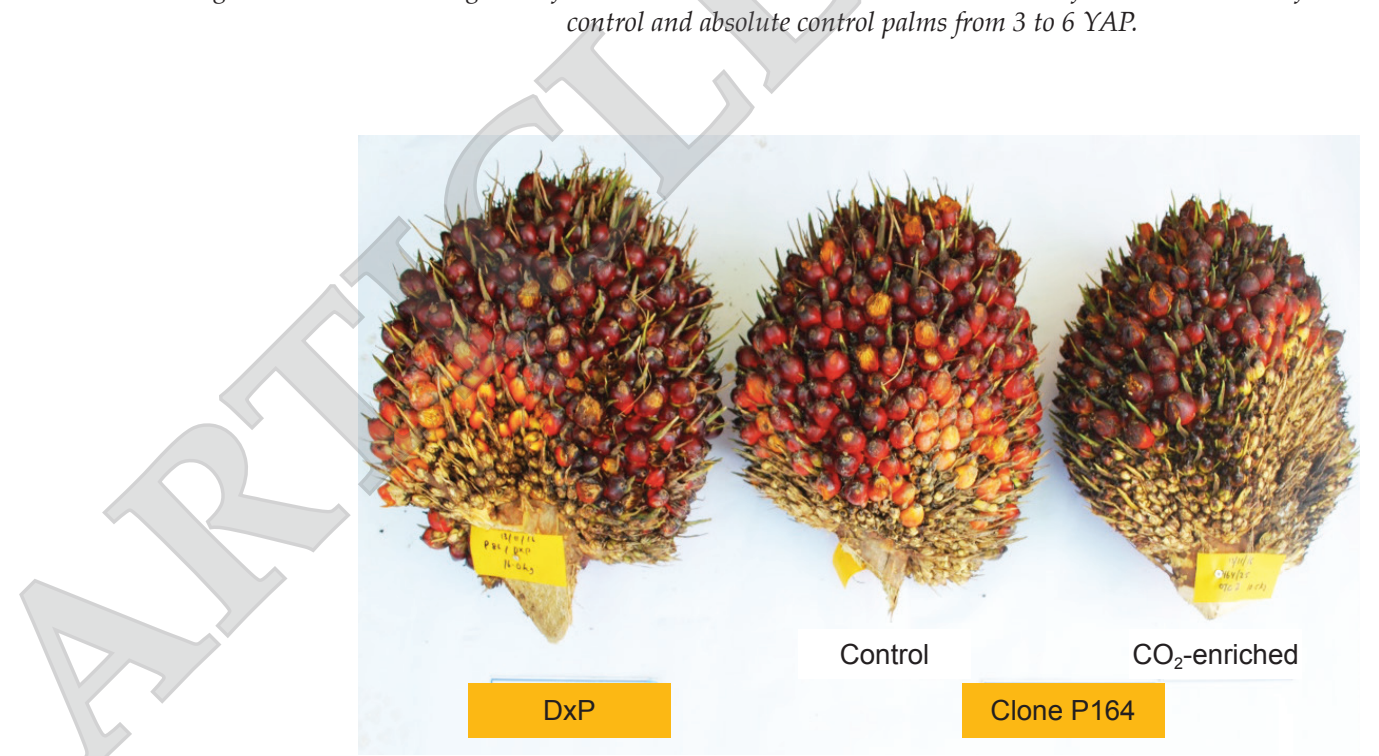

Figure 11. The comparison of fruit formation and fruit size of clone P164 (CO ${ }_{2}$-enriched and control $)$ and commercial DxP palm bunches at 6 YAP.

\section{ACKNOWLEDGEMENT}

The authors would like to thank the Director-General of MPOB for permission to publish this article and the staff of Crop Physiology Group for their assistance.

\section{REFERENCES}

Ainsworth, E A; Rogers, A; Blum, H; Nösberger, J and Long, S P (2003). Variation in acclimation of photosynthesis in Trifolium repens after eight years 
of exposure to free-air $\mathrm{CO}_{2}$ enrichment (FACE). J. Experimental Botany, 54: 2769-2774.

Ainsworth, E A and Long, S P (2005). What have we learned from 15 years of free-air $\mathrm{CO}_{2}$ enrichment (FACE)? A meta-analytic review of the responses of photosynthesis, canopy properties and plant production to rising $\mathrm{CO}_{2}$. New Phytologist, 165: 351372.

Aldrich, R A and Bartok, J W (1994). Greenhouse engineering. Carbon Dioxide Enrichment (Sailus, M; Chris, $\mathrm{N}$ and Sanders, $\mathrm{M}$ eds.). University of Connecticut Publication, Ithaca, New York. p. 118120.

Bakoumē, C; Ngando Ebonguē, G; Ajambang, W; Ataga, C D; Okoye, M N; Enabeme, L O; Konan, J N; Allou, D; Diabate, S; Konan, E and Etta, C E (2016). Oil palm breeding and seed production in Africa. Proc. of the International Seminar on Oil Palm Breeding and Seed Production and Field Visits. Kisaran, Indonesia. p. 39-62.

Barcelos, E; de Almeida Rios, S; Cunha, R N V; Lopes, R; Motoike, S Y; Babiychuk, E; Skirycz, A and Kushnir, S (2015). Oil palm natural diversity and the potential for yield improvement. Front. Plant Sci., 6: 1-16.

Bettarini, I; Vaccari, F P and Miglietta, F (1998). Elevated $\mathrm{CO}_{2}$ concentrations and stomatal density: Observations from 17 plants species growing in a $\mathrm{CO}_{2}$ spring in Central Italy. Glob. Chang. Biol., 4: 17-22.

Bindi, M; Hacour, A; Vendermeiren, K; Craigon, J; Ojanperä, K; Selldén, G; Högy, P; Finnan, J and Fibbi, L (2002). Chlorophyll concentration of potatoes grown under elevated carbon dioxide and / or ozone concentrations. European J. Agronomy, 17: 319-335.

Blaak, G; Sparnaaij, L D and Mendez, T (1963). Breeding and inheritance in the oil palm (Elaeis guineensis Jacq.). Part II. Methods of bunch quality analysis. J. West Afr. Inst. Oil Palm Res., 4: 146-155.

Bowes, G (1991). Growth at elevated $\mathrm{CO}_{2}$ : Photosynthetic responses mediated through rubisco. Plant, Cell and Environment, 14(8): 795-806.

Choo, Y M (2012). Malaysia: Economic transformation advances oil palm industry. The Amer. Oil Chem. Soc., 23(8): 536-542.

Conroy, J P and Hocking, P (1993). Nitrogen nutrition of $\mathrm{C}_{3}$ plants at elevated carbon dioxide concentration. Plant Physiology, 89: 570-576.
Corley, R H V and Tinker, P B (2003). The classification and morphology of oil palm. The Oil Palm. Fourth edition. Blackwell Science, Oxford, United Kingdom.

Corley, R H V; Hardon, J J and Tan, G Y (1971). Analysis of growth of the oil palm (Elaeis guineensis Jacq.). I. Estimation of growth parameters and application in breeding. Euphytica, 20: 307-315.

Curtis, P S and Wang, X (1998). A meta-analysis of elevated $\mathrm{CO}_{2}$ effects on woody plant mass, form and physiology. Oecologia, 113: 299-313.

Denis, J M (2017). Oil palm: Future prospects for yield and quality improvements. Lipid Technology, 21(11): 257-260.

Dhileepan, K (1994). Variation in populations of the introduced pollinating weevil (Elaeidobius kamerunicus) (Coleoptera: Curculionidae) and its impacts on fruitset of oil palm (Elaeis guineensis) in India. Bull. Entomol. Res., 84(4): 477-485.

Drake, B G; Gonzàlez-Meler, M A and Long, S P (1997). More efficient plants: A consequence of rising atmospheric $\mathrm{CO}_{2}$ ? Annu. Rev. Plant Physiol. Plant Mol. Biol., 48: 609-639.

Eamus, D (1991). The interaction of rising $\mathrm{CO}_{2}$ and temperatures with water use efficiency. Plant, Cell and Environment, 14: 843-852.

Ghildiyal, M C and Sharma-Natu, P (2000). Photosynthetic acclimation to rising atmospheric carbon dioxide concentration. Indian J. Exp. Biol., 38(10): 961-966.

Goudriaan, J and Unsworth, MH (1990). Implication of increasing carbon dioxide and climate change for agricultural productivity and water resources. Impact of Carbon Dioxide, Trace Gases and Climate Change on Global Agriculture. American Society of Agronomy, 53: 111-130.

Haniff, M H and Roslan, M N (2002). Fruit set and oil palm bunch components. J. Oil Palm Res., 14(2): 24-33.

Hardon, J J; Williams, C N and Watson, I (1969). Leaf area and yield in the oil palm in Malaya. Exp. Agric., 5(1): 25-32.

Hawa, Z E J (2004). Response of Brassica chinensis var. chinensis under $\mathrm{CO}_{2}$-enriched controlled environment production system in the tropics. Transactions of Malaysian Society of Plant Physiology Vol. 13. 
Ibrahim, M H; Hawa, Z E J; Harun, M H and Yusop, M R (2010). Changes in growth and photosynthetic patterns of oil palm (Elaeis guineensis Jacq.) seedlings exposed to short-term $\mathrm{CO}_{2}$ enrichment in a closed top chamber. Acta Physio. Plant., 32(2): 305-313.

Idso, S B and Kimball, B A (1992). Effects of atmospheric $\mathrm{CO}_{2}$ enrichment on photosynthesis, respiration, and growth of sour orange trees. Plant Physiol., 99(1): 341-343.

Idso, S B; Kimball, B A and Hendrix, D L (1996). Effects of atmospheric $\mathrm{CO}_{2}$ enrichment on chlorophyll and nitrogen concentrations of sour orange tree leaves. Environ. Exp. Bot., 36(3): 323331.

Intergovernmental Panel on Climate Change (IPCC) (2007). Climate change 2007: The physical science basis. Contribution of Working Group I to The Forth Assessment Report of the IPCC (Solomon, S; Qin, D; Manning, M; Chen, Z; Marquis, M; Averyt, $\mathrm{K}$ B; Tignor, $\mathrm{M}$ and Miller, $\mathrm{H}$ L eds.). Cambridge University Press. United Kingdom. 996 pp.

Jach, M E and Ceulemans, R (1999). Effects of elevated atmospheric $\mathrm{CO}_{2}$ on phenology, growth and crown structure of Scots pine (Pines sylvestris) seedlings after two years of exposure in the field. The Physiol., 19: 289-300.

Jeffrey, D H and Richard, B T (1999). Effects of carbon dioxide enrichment on the photosynthetic light response of sun and shade leaves of canopy sweetgum trees (Liquidambar styraciflua) in a forest ecosystem. Tree Physiol., 19: 779-786.

Kimball, B A; Zhu, J; Chong, L; Kobayaki, K and Bindi, M (2002). Responses of agricultural crops of free-air $\mathrm{CO}_{2}$ enrichment. The J. Applied Ecology, 13(10): 1323-1338.

Kirschbaum, M U F and McMilan, A M S (2018). Warming and elevated $\mathrm{CO}_{2}$ have opposing influences on transpiration. Which is more important? Curr. Forestry Rep., 4(2): 51-71.

Kushairi, A; Loh, S K; Azman, I; Elina, H; Meilina, O A; Zanal Bidin, M N I; Razmah, G; Sundram, S and Parveez, G K A (2018). Oil palm economic performance in Malaysia and $R \& D$ progress in 2017. J. Oil Palm Res., 30(2): 163-195.

Li, F; Kang, S; Zhang, J and Cohen, S (2003). Effects of atmospheric $\mathrm{CO}_{2}$ enrichment, water status and applied nitrogen on water and nitrogen-use efficiencies of wheat. Plant and Soil, 254(2): 279289.
Li, J; Zhou, J M and Duan, Z Q (2007). Effects of elevated $\mathrm{CO}_{2}$ concentration on growth and water usage of tomato seedlings under different ammonium-nitrate ratios. J. Environ. Sci. (China), 19(9): 1100-1107.

Liberloo, M; Calfapietra, C; Lukac, M; Godbold, D; Luo, Z B; Polle, A; Hoosbeek, M R; Kull, O; Marek, M; Raines, C; Rubino, M; Taylor, G; ScarasciaMugnozza, G and Ceulemans, R (2006). Woody biomass production during the second rotation of a bio-energy Populus plantation increases in a future high $\mathrm{CO}_{2}$ world. Glob. Chang. Biol., 12(6): 1094-1106.

Makino, A and Mae, T (1999). Photosynthesis and plant growth at elevated levels of $\mathrm{CO}_{2}$. Plant Cell Physiol., 40(10): 999-1006.

Marschner, H (1995). Nutritional physiology. Mineral Nutrition of Higher Plants. Second edition. Academic Press London, United Kingdom. p. 131183.

Medlyn, B E; Barton, C V M; Broadmeadow, M S J; Ceulemans, R; De Angelis, P; Forstreuter, M; Freeman, M; Jackson, S B; Kellömaki, S; Laitat, E; Rey, A; Roberntz, P; Sigurdsson, B D; Strassemeyer, J; Wang, K; Curtis, P S and Jarvis, P G (2001). Stomatal conductance of forest species after longterm exposure to elevated $\mathrm{CO}_{2}$ concentration: A synthesis. New Phytol., 149(2): 247-264.

Murray, M B; Smith, R I; Friend, A and Jarvis, P $G$ (2000). Effects of elevated $\left(\mathrm{CO}_{2}\right)$ and varying nutrient application rates on physiology and biomass accumulation of Sitka spruce (Picea sitchensis). Tree Physiol., 20(7): 421-434.

Paoletti, E and Gellini, R (1993). Stomatal density variation in beech and holm oak leaves collected over the last 200 years. Acta Oecologia, 14: 173178.

Peńuelas, J and Matamala, R (1990). Changes in N and $\mathrm{S}$ leaf content, stomatal density and specific leaf area of 14 plant species during the last three centuries of $\mathrm{CO}_{2}$ increase. J. Exp. Bot., 41(9): 11191124.

Pidwirny, M (2006). Introduction to the atmosphere. Fundamentals of Physical Geography $2^{\text {nd }}$ Edition (Sack, D; Petersen, J F and Gabler, R E eds.) http: / / www. physicalgeography.net/fundamentals / 8b.html, accessed on 20 September 2011.

Radoglou, K M and Jarvis, P G (1990). Effects of CO $\mathrm{CO}_{2}$ enrichment on four Poplar clones. II. Leaf surface properties. Ann. Bot., 65(6): 627-632. 
Tarmizi, M A (2009). Pembajaan sawit. Perusahaan Sawit di Malaysia. Edisi Ketiga (Esnan, A G and Idris, O eds.). MPOB, Bangi. p. 149-163.

Thompson, M; Gamage, D; Hirotsu, N; Martin, A and Seneweera, S (2017). Effects of elevated carbon dioxide on photosynthesis and carbon partitioning: A perspective on root sugar sensing and hormonal crosstalk. Front. Physiol., 8: 578-589.

Tyree, M T and Alexander, J D (1993). Plant water relations and the effects of elevated $\mathrm{CO}_{2}$ : A review and suggestions for future research. Vegetatio, 104: 47-62.

Warren, J M; Jensen, A M; Medlyn, B E; Norby, R J and Tissue, D T (2014). Carbon dioxide stimulation of photosynthesis in Liquidambar styraciflua is not sustained during a 12-year field experiment. $A o B$ Plants, 7: 1-13.

Wulff, R D and Strain, B R (1981). Effects of $\mathrm{CO}_{2}$ enrichment on growth and photosynthesis in Desmodium paniculatum. Can. J. Bot., 60(7): 10841091.

Xu, Z; Jiang, Y; Jia, B and Zhou, G (2016). Elevated $\mathrm{CO}_{2}$ response of stomata and its dependence on environmental factors. Front. Plant Sci., 7: 657670.

Ziska, L H (2008). Rising atmospheric carbon dioxide and plant biology: The overlooked paradigm. DNA Cell Biol., 27(4): 165-172. 